\title{
Article/Artigo
}

\section{Leishmanicidal activity and cytotoxicity of compounds from two Annonacea species cultivated in Northeastern Brazil}

\author{
Atividade leishmanicida e citotoxicidade de constituintes químicos de duas espécies de \\ Annonaceae cultivadas no nordeste do Brasil
}

\author{
Nadja Soares Vila-Nova ${ }^{1}$, Selen Maia de Morais ${ }^{1,2}$, Maria José Cajazeiras Falcão ${ }^{2}$, Lyeghyna Karla Andrade Machado ${ }^{2}$, \\ Cláudia Maria Leal Beviláqua', Igor Rafael Sousa Costa ${ }^{2}$, Nilce Viana Gramosa Pompeu de Sousa Brasil ${ }^{3}$ \\ and Heitor Franco de Andrade Júnior ${ }^{4}$
}

\begin{abstract}
Introduction: Visceral leishmaniasis is endemic in 88 countries, with a total of 12 million people infected and 350 million at risk. In the search for new leishmanicidal agents, alkaloids and acetogenins isolated from leaves of Annona squamosa and seeds of Annona muricata were tested against promastigote and amastigote forms of Leishmania chagasi. Methods: Methanol-water (80:20) extracts of $A$. squamosa leaves and $A$. muricata seeds were extracted with $10 \%$ phosphoric acid and organic solvents to obtain the alkaloid and acetogenin-rich extracts. These extracts were chromatographed on a silica gel column and eluted with a mixture of several solvents in crescent order of polarity. The compounds were identified by spectroscopic analysis. The isolated compounds were tested against Leishmania chagasi, which is responsible for American visceral leishmaniasis, using the MTT test assay. The cytotoxicity assay was evaluated for all isolated compounds, and for this assay, RAW 264.7 cells were used. Results: $O$-methylarmepavine, a benzylisoquinolinic alkaloid, and a $\mathrm{C}_{37}$ trihydroxy adjacent bistetrahydrofuran acetogenin were isolated from A. squamosa, while two acetogenins, annonacinone and corossolone, were isolated from A. muricata. Against promastigotes, the alkaloid showed an $\mathrm{IC}_{50}$ of $23.3 \mu \mathrm{g} / \mathrm{mL}$, and the acetogenins showed an $\mathrm{IC}_{50}$ ranging from 25.9 to $37.6 \mu \mathrm{g} / \mathrm{mL}$; in the amastigote assay, the $\mathrm{IC}_{50}$ values ranged from 13.5 to $28.7 \mu \mathrm{g} / \mathrm{mL}$. The cytotoxicity assay showed results ranging from 43.5 to $79.9 \mu \mathrm{g} / \mathrm{mL}$. Conclusions: These results characterize $A$. squamosa and $A$. muricata as potential sources of leishmanicidal agents. Plants from Annonaceae are rich sources of natural compounds and an important tool in the search for new leishmanicidal therapies.
\end{abstract}

Keywords: Leishmaniasis. Benzylisoquinolinic alkaloids. Acetogenins. Annona squamosa. Annona muricata.

\section{RESUMO}

Introdução: A leishmaniose visceral é uma enfermidade endêmica em 88 países, com um total de 12 milhões de pessoas infectadas e 350 milhões em risco. Na procura de novos agentes com ação leishmanicida, alcalóides e acetogeninas isoladas de Annona squamosa e Annona muricata, foram testados contra as formas promastigotas e amastigotas de Leishmania chagasi. Métodos: Foram preparados extratos com metanol: água (80:20) das folhas de A. squamosa e sementes de A. muricata que foram extraídos com solução de ácido fosfórico $10 \%$ e solventes orgânicos, para obter extratos ricos em alcalóides e acetogeninas. Estes extratos foram cromatografados em coluna de sílica gel sendo eluídos com solventes de diferentes polaridades para o isolamento dos constituintes, e feita a determinação estrutural por análise espectroscópica. Os constituintes isolados foram testados contra Leishmania chagasi, responsável pela leishmaniose visceral, utilizando o teste MTT. Testes de toxicidade foram realizados em todos os compostos isolados, sendo utilizadas células RAW 264.7. Resultados: Um alcalóide benzilisoquinolínico, O-metilarmepavina, e uma $\mathrm{C}_{37}$-triidróxi-acetogenina com anel bistetrahidrofurânico adjacente foram isolados de $A$. squamosa e duas acetogeninas annonacinona e corossolona da $A$. muricata. $\mathrm{O}$ alcalóide mostrou um índice de inibição médio $\left(\mathrm{IC}_{50}\right)$ de $23,3 \mu \mathrm{g} / \mathrm{mL}$ e as acetogeninas apresentaram $\mathrm{IC}_{50}$ variando entre $25,9 \mathrm{a}$ $37,6 \mu \mathrm{g} / \mathrm{mL}$ contra promastigotas, e no ensaio de amastigotas, $\mathrm{oIC}$ valores variaram entre 13,5 a 28,7 $\mu \mathrm{g} / \mathrm{mL}$. A toxicidade mostrou resultados que variaram entre 43,5 a $79,9 \mu \mathrm{g} / \mathrm{mL}$. Conclusões: Estes resultados caracterizam A. squamosa e A. muricata como fontes potenciais de agentes leishmanicidas. Palavras-chaves: Leishmaniose. Alcaloide benzilisoquinolinico. Acetogenina. Annona squamosa. Annona muricata.

1. Programa de Pós-Graduação em Ciências Veterinárias, Faculdade de Medicina Veterinária, Universidade Estadual do Ceará, Fortaleza, CE. 2. Curso de Química, Centro de Ciências e Tecnologia, Universidade Estadual do Ceará, Fortaleza, CE. 3. Departamento de Química Orgânica e Inorgânica, Centro de Ciências, Universidade Federal do Ceará, Fortaleza, CE. 4. Instituto de Medicina Tropical, Laboratório de Protozoologia, Universidade de São Paulo, São Paulo, SP.

Address to: Dra. Selene Maia de Morais. Rua Ana Bilhar 601/400, Meireles, 60160-110 Fortaleza, CE, Brasil. Phone: 5585 3242-6811; 5585 3101-9933

e-mail: selene.maia@pq.cnpq.br

Received in 15/03/2011

Accepted in 07/06/2011

\section{INTRODUCTION}

Leishmaniasis is a tropical zoonotic disease caused by at least 17 protozoa species of the Leishmania genus ${ }^{1}$. The forms of the disease are related to the type of parasite and differ in geographic distribution, the host and vector involved, incidence rate, and mortality ${ }^{2}$. Visceral leishmaniasis is endemic in 88 countries, with a prevalence of 12 million people, causing 500,000 cases a year, besides those cases of asymptomatic individuals that are not diagnosed ${ }^{3,4}$.

The chemotherapy of leishmaniasis is based on the use of toxic heavy metal-based compounds, particularly pentavalent antimonials. However, these compounds must be administered over prolonged periods and are often associated with serious side effects, including cardiotoxicity, pancreatitis, and musculoskeletal affections, when used at therapeutic doses. Other treatments for leishmaniasis, such as amphotericin B and pentamidine, are associated with multiple adverse side effects, such as bone marrow suppression, renal toxicity, and glucose metabolism disturbances ${ }^{1,5,6}$.

Plants that are traditionally used for treatment of several diseases caused by protozoa are attracting attention in tests against different Leishmania species. Leishmanicidal acetogenins and alkaloids from the Annonacea species have demonstrated the great potential of this plant family as a source of leishmanicidal agents ${ }^{5,7}$.

In Northeastern Brazil, two species of Annonacea are largely cultivated due to their characteristics of edibility and high amount of waste material for the pulp industry and other markets. To make use of this discharged material, this study aimed to evaluate, in vitro, the effectiveness of constituents from A. squamosa leaves and $A$. muricata seeds against the promastigote and amastigote forms of Leishmania (L.) chagasi. 


\section{METHODS}

\section{Plant materials}

Leaves of $A$. squamosa and A. muricata were collected from the Ceará State University campus in Fortaleza, State of Ceará, Brazil. The aerial parts of the plants were deposited in the Prisco Bezerra Herbarium under reference numbers 43,604 and 43,951, respectively.

\section{Isolation of compounds and spectroscopic identification}

The plant materials ( $2 \mathrm{~kg}$ ) were powdered, air-dried, immersed in a methanol- $\mathrm{H}_{2} \mathrm{O}$ solution $(80: 20,1.51)$, and left for 7 days at room temperature. After this period, the solvent was eliminated using a rotative evaporator, leaving the crude extract (CE). Part of the $\mathrm{CE}$ was dissolved with $10 \%$ phosphoric acid and then the aqueous acid mixture was washed with dichloromethane. The organic phase was evaporated to dryness to obtain an acetogenin-rich extract (ACE, $82 \mathrm{~g}$ ). The ACE was submitted to silica gel column chromatography, being eluted with hexane, dichloromethane, ethyl acetate, and methanol in mixtures of increasing polarity. The fractions were collected and compared in thin layer chromatographic (TLC) plates sprayed with Kedde's reagent to reveal the acetogenins. Ammonium hydroxide was added to the aqueous acid solution until $\mathrm{pH}$ 9, after which the solution was partitioned with dichloromethane. Dragendorff's reagent was used until a negative reaction was seen. The dichloromethane phase was dried over sodium sulfate and concentrated under reduced pressure until complete dryness to obtain the total alkaloid extract (AE, $0.58 \mathrm{~g}$ ). This extract was submitted to the same silica gel column chromatographic treatment as above, using Dragendorff's reagent for spraying the TLC plates. The chemical structures of the isolated compounds were determined by spectroscopic analysis of infrared spectra, recorded on a PerkinElmer 100 FT-IR spectrophotometer; the values were expressed in $\mathrm{cm}^{-1}$, and the nuclear magnetic resonance spectra were recorded on a Bruker Avance DRX-500 spectrometer in $\mathrm{CDCl}_{3}$.

\section{Parasites}

Leishmania (L.) chagasi (M6445 strain) promastigotes were cultured in M199 medium supplemented with $10 \%$ fetal bovine serum and $5 \%$ human male urine at $24^{\circ} \mathrm{C}$. RAW 264.7 murine macrophages (ATCC TIB-71) were maintained in RPMI-1640 medium supplemented with $10 \%$ fetal bovine serum at $37^{\circ} \mathrm{C}$ in a $5 \%$ $\mathrm{CO}_{2}$ humidified incubator and seeded for $24 \mathrm{~h}$ at $4.10^{5}$ cells per well in 96-well plates before infection with $L$. chagasi promastigotes. The amastigotes were obtained from RAW 264.7 murine macrophage cells infected with promastigote at a ratio of 1:10 (macrophage/ promastigote), kept in a $5 \% \mathrm{CO}_{2}$ humidified incubator for $72 \mathrm{~h}$ at $37^{\circ} \mathrm{C}$, and then analyzed under a light microscope to confirm infection.

\section{Leishmanicidal activity}

Test against promastigotes: To determine the 50\% effective concentration $\left(\mathrm{EC}_{50}\right.$ value) of the compounds against $L$. chagasi promastigotes, all compounds were dissolved previously in ethanol at a concentration of $0.2 \%$ and diluted with M199 medium in 96well microplates. The assay was performed at concentrations of $100,50,25,12.5$, and $6.25 \mu \mathrm{g} / \mathrm{mL}$, and controls with ethanol and without drugs were performed. Each concentration was tested nine times. Promastigotes were counted in a Neubauer haemocytometer and seeded at $1 \times 10^{6}$ cells per well for a final volume of $150 \mu$ l. The plates were incubated at $24^{\circ} \mathrm{C}$ for $24 \mathrm{~h}$, and the viability of the promastigotes was assessed by morphological observation under a light microscope. Diphenyltetrazolium (MTT) assay was performed; initially, MTT $(5 \mathrm{mg} / \mathrm{mL})$ was dissolved in PBS and sterilized through $0.22-\mu \mathrm{m}$ membranes, and then $20 \mu \mathrm{l} /$ well was added to a 96 -well plate and left at $37^{\circ} \mathrm{C}$ for $4 \mathrm{~h}$. Promastigotes were incubated without compounds and used as viability control. Formazan extraction was performed using $10 \%$ SDS $(100 \mathrm{~mL} /$ well $)$ at $24^{\circ} \mathrm{C}$ for $18 \mathrm{~h}$, and the optical density (OD) at $570 \mathrm{~nm}$ was determined in a Multiskan MS spectrophotometer (UniScience). Pentamidine (Ítaca Laboratórios Ltda, Rio de Janeiro, Brazil) was used as standard drug $(50 \mathrm{mg} / \mathrm{mL})$.

Test against amastigotes: To determine the $\mathrm{EC}_{50}$ value of the compounds against $L$. chagasi amastigotes, all compounds were dissolved in $0.2 \%$ ethanol at concentrations of $100,50,25,12.5$, and $6.25 \mu \mathrm{g} / \mathrm{mL}$ and added to microplates containing a confluent layer of cells with amastigotes for $48 \mathrm{~h}$ at $37^{\circ} \mathrm{C}$ in a $5 \% \mathrm{CO}_{2}$ humified incubator. Glucantime was used as standard drug, and macrophages incubated without drugs were used as control. For the in vitro assay, an adapted methodology from Piazza et al. ${ }^{8}$ was used. The RAW 264.7 cells were incubated with $0.01 \%$ saponin in PBSA containing $1 \%$ bovine serum albumin for $30 \mathrm{~min}$. After blocking the wells for 30 min with 5\% defatted milk (Nestlé) in PBSA, the cells were incubated at $37^{\circ} \mathrm{C}$ for $1 \mathrm{~h}$ with serum from a rabbit immunized with saline extract of $L$. chagasi promastigotes, collected 30 days after the infection. The serum employed was diluted at 1:500 and pre-absorbed with $10 \%$ fetal calf serum (FCS) at $22^{\circ} \mathrm{C}$ for $1 \mathrm{~h}$. After washing the wells three times with $0.05 \%$ Tween 20 in PBSA, peroxidase-conjugated goat anti-rabbit IgG (Sigma Chemical Co.), diluted 1:5,000 in 5\% defatted milk was added, and the mixture was left at $37^{\circ} \mathrm{C}$ for $\mathrm{lh}$. The wells were washed three times, after which $o$-phenylenediamine $(0.4 \mathrm{mg} / \mathrm{mL})$ and $0.05 \% \mathrm{H}_{2} 0_{2}$ were added. The solution was then transferred to ELISA microplates. The reaction was stopped by adding $1 \mathrm{M} \mathrm{HC} 1$, and the plates read at $492 \mathrm{~nm}$ in a Titertek Multiskan ELISA reader.

\section{Cytotoxicity assay}

For the cytotoxicity assay, an adapted methodology from Tempone (2005) was used. RAW 264.7 murine macrophage cells were seeded at $4 \times 10^{4}$ cells per well in 96-well microplates and incubated at $37^{\circ} \mathrm{C}$ for $48 \mathrm{~h}$ in the presence of the compounds, dissolved previously in ethanol at a concentration of $0.2 \%$ and diluted with M199 medium to the highest concentration of $120 \mu \mathrm{g} / \mathrm{mL}$. The microplates were incubated for $48 \mathrm{~h}$ at $37^{\circ} \mathrm{C}$ in a $5 \% \mathrm{CO}_{2}$ humidified incubator. Control cells were incubated in the presence of DMSO, without drugs, Glucantime, and pentamidine (standard drugs). The viability of the macrophages was determined with the MTT assay, as described above, and was confirmed by comparing the morphology of the control group via light microscopy.

\section{Statistical analysis}

The $\mathrm{EC}_{50}$ values at $95 \%$ confidence interval (CI) were calculated using a nonlinear regression curve. One-way ANOVA and comparative analysis between treatments were performed by Tukey's parametric test using the number of living promastigotes and amastigotes determined indirectly by the optical density (OD, $570 \mathrm{~nm}$ ), representing the percentage of survival and/or murine macrophage cells after normalization using the statistical software GraphPad Prism 4.0. 


\section{RESULTS}

The silica gel column chromatography of the alkaloid extract of $A$. squamosa leaves led to the isolation of O-methylarmepavine (I), a benzylisoquinolinic alkaloid; and from the methanol extract free from alkaloids, a $\mathrm{C}_{37}$ trihydroxy adjacent bistetrahydrofuran acetogenin (II) was isolated (Figure 1). This acetogenin was shown to be identical, when compared by thin layer chromatography (TLC) and spectroscopic data, with the acetogenin previously identified in A. squamosa seeds, which showed anthelmintic activity against Haemonchus contortus, the main nematode in small ruminants in Northeastern Brazil ${ }^{9}$. The complete assignment of carbons and hydrogens for the structure of $\mathrm{O}$-methylarmepavine was performed using one- and two-dimensional NMR spectral analysis and by comparison with data from previous studies ${ }^{10,11}$.

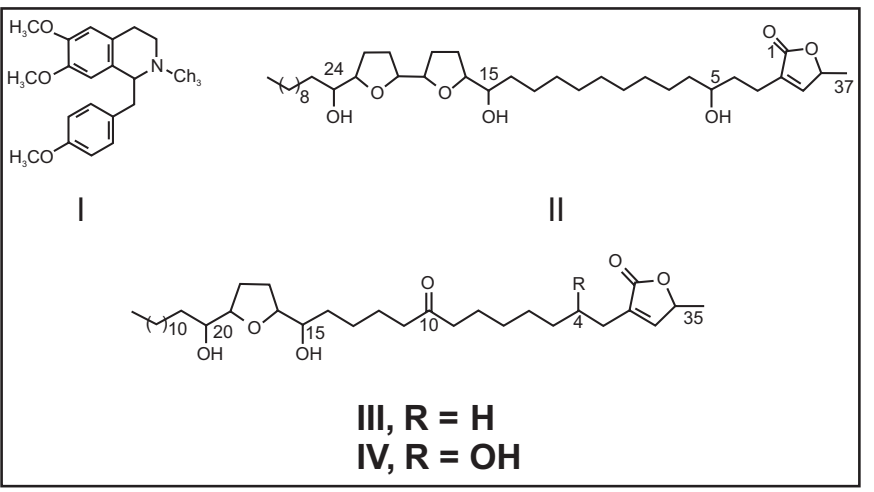

FIGURE 1 - Chemical structures of the leishmanicidal compounds $O$-methylarmepavine (I) and $\mathrm{C}_{37}$ trihydroxy adjacent bistetrahydrofuran acetogenin (II) from A. squamosa and Corossolone (III) and Annonacinone (IV) from A. muricata.

Compound I was isolated as a brown solid: m.p.: $49.9-50.7^{\circ} \mathrm{C}$; $\mathrm{UV}\left(\lambda_{\max }, \mathrm{MeOH}, \mathrm{nm}\right): 225$ ( $\left.\log \varepsilon 3.19\right) ; \mathrm{IR}(\mathrm{KBr}) \delta_{\max } 2.935$, $1.612,1.514,1.460,1.250,1.118,1.068,1.033,833 \mathrm{~cm}^{-1} ;{ }^{1} \mathrm{H}$ NMR $\left(\mathrm{CDCl}_{3}, 500 \mathrm{MHz}\right) 5.83(\mathrm{H1}), 6.58(\mathrm{H} 4, \mathrm{~s}), 2.2-2.4(\mathrm{H} 5, \mathrm{~m}), 3.10$ (H6a, d, 7.0), 3.39 (H6b, t, 7.15), 4.32 (H7a, m), 2.78 (H8, t, 6.4), $7.0(\mathrm{H} 9 / \mathrm{H} 13, \mathrm{~d}, 8.4), 6.79(\mathrm{H} 10 / \mathrm{H} 12, \mathrm{~d}, 8.4), 3.48\left(\mathrm{OCH}_{3}\right), 3.82$ $\left(\mathrm{OCH}_{3}\right), 3.77\left(\mathrm{OCH}_{3}\right), 2.64\left(\mathrm{~N}-\mathrm{CH}_{3}\right)$ and ${ }^{13} \mathrm{C} \mathrm{NMR} 65.05(\mathrm{C} 1)$, 149.45 (C2), 147.49 (C3), 111.24 (C4), 22.02 (C5), 44.94 (C6), 65.45 (C7a), 40.25 (C8), 114.27 (C9/C13), 131.17 (C10/C12), 159.21 (C11), 122 (C14), 121 (C15), $122(\mathrm{C} 16), 55.72\left(\mathrm{OCH}_{3}\right)$, $56.06\left(\mathrm{OCH}_{3}\right), 55.86\left(\mathrm{OCH}_{3}\right), 40.44\left(\mathrm{~N}-\mathrm{CH}_{3}\right)$.

Compound II was isolated as a viscous oil: $\mathrm{UV}\left(\lambda_{\max }, \mathrm{MeOH}, \mathrm{nm}\right)$ : $281(\log \varepsilon 3.41) ; \mathrm{IR}(\mathrm{KBr}) \lambda_{\max } 3.418,2.927,2.855,1.748,1.652$, $1.463,1.319,1.118,1.068,1.028,953,877,756,666 \mathrm{~cm}^{-1} ;{ }^{1} \mathrm{H}$ NMR $\left(\mathrm{CDCl}_{3}, 500 \mathrm{MHz}\right) 2.29(\mathrm{H} 3, \mathrm{t} 7.8), 1.56(\mathrm{H} 4, \mathrm{~m}), 3.62(\mathrm{H} 5, \mathrm{~m})$, 1.55 (H6, m), 1.28 (H7, m), 1.28 (H8-12, m), 1.28 (C13, m), 1.56 (H14, m), 3.34 (H15, m), 3.84 (H16, m), 1.98 (H17a, m), 1.65 (H17b, m), 1.98 (H18a, m), 1.65 (H18b, m), 3.94 (H19, m), 3.94 (H20, m), 1.98 (H21a, m), 1.65 (H21b, m), 1.98 (H22a, m), 1.65 (H22b, m), $3.84(\mathrm{H} 23, \mathrm{~m}), 3.43$ (H24, m), 1.56 (H25, m), 1.28 (H26, m), 1.28 (H27,31, m), 1.28 (H32, m), 1.28 (H33, m), 0.90 (H34, t 7.0), 6.99

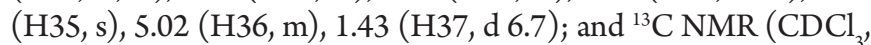
$125 \mathrm{MHz}) 173.8(\mathrm{C} 1), 134.2(\mathrm{C} 2), 25.6(\mathrm{C} 3), 37.1(\mathrm{C} 4), 71.7(\mathrm{C} 5)$, 37.3 (C6), 24.8 (C7), 28.9-29.6 (C8-12), 25.1 (C13), 33.0 (C14), 74.1 (C15), 83.2* (C16), 27.3 (C17), 28.4 (C18), 82.5* (C19), 82.1* (C20), 28.4 (C21), 27.3 (C22), 82.7* (C23), 71.4(C24), 32.3 (C25), 25.6 (C26), 28.9-29.6 (27-31), 31.8 (C32), 22.5 (C33), 14.0 (C34), 148.9 (C35), 77.4 (C36), 19.1 (C37). *Values are exchangeable.
The ${ }^{1} \mathrm{H}$ and ${ }^{13} \mathrm{C}-\mathrm{NMR}$ spectral data of compounds III and IV (Table 1) indicate the characteristics of y-lactone mono-tetrahydrofurans with a keto group (peak at $\delta 211.60$ for compound III and at $\delta 211.55$ for compound IV in $\left.{ }^{13} \mathrm{C}-\mathrm{NMR}\right)$, differing in the number of hydroxyl groups. Compound III, which is less polar, shows two hydroxyls located at C15, $\delta 74.15$ and at $\mathrm{C} 20, \delta 74.00$ in the ${ }^{13} \mathrm{C}-\mathrm{NMR}$ spectra; these data were compared with those for corossolone, which was previously isolated by Cortes et al. ${ }^{12}$ Compound IV, with three hydroxyls linked to $\mathrm{C} 15$, $\delta 74.32$; $C 20, \delta 74.01$; and $C 4, \delta 70.01$ was compared with the structure of annonacinone ${ }^{13}$. The structures of corossolone (III) and annonacinone (IV) are shown in Figure 1.

TABLE $1-{ }^{1} \mathrm{H}\left(\mathrm{CDCl}_{3}, 500 \mathrm{MHz}\right)$ and ${ }^{13} \mathrm{C}-\mathrm{NMR}\left(\mathrm{CDCl}_{3}, 125 \mathrm{MHz}\right)$ chemical shifts of compounds III and IV isolated from Annona muricata.

\begin{tabular}{|c|c|c|c|c|}
\hline Compound (C) & $\begin{array}{l}\text { III } \\
1_{H}\end{array}$ & $\begin{array}{c}\text { III } \\
{ }^{13} \mathrm{C}\end{array}$ & $\begin{array}{l}\text { IV } \\
1_{H}\end{array}$ & $\begin{array}{c}\text { IV } \\
{ }^{13} \mathrm{C}\end{array}$ \\
\hline 1 & - & 174.84 & - & 174.08 \\
\hline 2 & - & 131.31 & - & 134.45 \\
\hline $3 a$ & 2.39 & - & - & - \\
\hline $3 b$ & 2.50 & 33.64 & 2.26 & 25.31 \\
\hline 4 & 3.83 & 70.01 & $1.52-1.58$ & 27.55 \\
\hline 5 & $1.25-1.29$ & 37.30 & 1.31 & $28.97-29.92$ \\
\hline 6-7 & $1.25-1.29$ & $29.20-29.92$ & 1.31 & $28.97-29.92$ \\
\hline 8 & 1.55 & 23.99 & $1.52-1.58$ & 23.97 \\
\hline 9 & 2.38 & 42.79 & $2.37-2.43$ & 42.99 \\
\hline 10 & - & 211.60 & - & 211.55 \\
\hline 11 & 2.38 & 42.88 & $2.37-2.43$ & 42.91 \\
\hline 12 & 1.55 & 23.84 & $1.52-1.58$ & 25.35 \\
\hline 13 & $1.25-1.29$ & 25.42 & 1.31 & 25.47 \\
\hline 14 & 1.38 & 33.64 & 1.38 & 33.45 \\
\hline 15 & 3.49 & 74.32 & 3.40 & 74.15 \\
\hline 16 & 3.80 & 82.75 & 3.79 & 82.79 \\
\hline $17-18$ & $1.64-1.98$ & 28.96 & $1.68-1.98$ & 29.01 \\
\hline 19 & 3.80 & 82.89 & 3.79 & 82.89 \\
\hline 20 & 3.40 & 74.02 & 3.40 & 74.00 \\
\hline 21 & 1.39 & 33.59 & 1.38 & 33.70 \\
\hline 22 & $1.25-1.29$ & 25.78 & 1.31 & 25.80 \\
\hline $23-29$ & $1.25-1.29$ & $29.20-29.92$ & 1.31 & $28.97-29.92$ \\
\hline 30 & $1.25-1.29$ & 32.11 & 1.31 & 32.12 \\
\hline 31 & $1.25-1.29$ & 22.88 & 1.31 & 22.89 \\
\hline 32 & 0.87 & 14.32 & 0.89 & 14.32 \\
\hline 33 & 7.18 & 152.12 & 6.99 & 149.15 \\
\hline 34 & 5.05 & 78.21 & 4.99 & 77.62 \\
\hline 35 & 1.39 & 19.29 & 1.38 & 19.42 \\
\hline
\end{tabular}

In the search for new drugs with leishmanicidal activity, A. squamosa and A. muricata constituents were tested against L. chagasi promastigotes. In this assay, pentamidine was used as standard drug and showed an $\mathrm{EC}_{50}$ value of $1.63 \mu \mathrm{g} / \mathrm{mL}$; the acetogenin from $A$. squamosa showed an $\mathrm{IC}_{50}$ value of $26.4 \mu \mathrm{g} / \mathrm{mL}$, and the alkaloid $O$-methylarmepavine showed an $\mathrm{IC}_{50}$ value of $23.3 \mu \mathrm{g} / \mathrm{mL}$. The assay using annonacinone and corossolone isolated from $A$. muricata showed $\mathrm{IC}_{50}$ values of 37.6 and $25.9 \mu \mathrm{g} / \mathrm{mL}$, respectively (Table 2).

In the amastigote assay, compounds I and II showed IC $_{50}$ values of 25.3 and $25.4 \mu \mathrm{g} / \mathrm{mL}$, respectively, and compounds III and IV showed $\mathrm{IC}_{50}$ values of 13.5 and $28.7 \mu \mathrm{g} / \mathrm{mL}$, respectively, which were statistically similar. The standard drug used, pentamidine, showed an $\mathrm{IC}_{50}$ value of $1.60 \mu \mathrm{g} / \mathrm{mL}$ (Table 2). 
TABLE 2 - Effect of Annona squamosa and Annona muricata compounds and standards on extra-extracellular promastigote and intra-intracellular amastigote forms of Leishmania chagasi and their cytotoxicity in mammalian cells.

$\begin{array}{ccc}{ }^{*} \mathrm{EC}_{50} & { }^{*} \mathrm{EC}_{50} & \mathrm{EC}_{50} \mathrm{y} \\ \text { promastigotes } & \text { amastigotes } & \text { cytotoxicit }\end{array}$

\begin{tabular}{lccc} 
Compounds & $(\mu \mathrm{g} / \mathrm{mL})(95 \% \mathrm{CI})$ & $(\mu \mathrm{g} / \mathrm{mL})(95 \% \mathrm{CI})$ & $(\mu \mathrm{g} / \mathrm{mL})(95 \% \mathrm{CI})$ \\
\hline Alkaloid (I) & $23.3^{\mathrm{a}}(12.3-38.7)$ & $25.4^{\mathrm{a}}(6.1-105.9)$ & $79.7^{\mathrm{a}}(9.3-61.8)$ \\
\hline Acetogenin (II) & $26.4^{\mathrm{a}}(22.6-98-5)$ & $25.3^{\mathrm{a}}(22.7-28.1)$ & $43.5^{\mathrm{b}}(23-129.1)$ \\
\hline Acetogenin (III) & $25.9^{\mathrm{a}}(7.6-88.2)$ & $28.7^{\mathrm{a}}(6.2-67.4)$ & $54^{\mathrm{b}}(28.3-119.7)$ \\
\hline Acetogenin (IV) & $37.6^{\mathrm{a}}(25.8-54.80)$ & $13.5^{\mathrm{b}}(2.1-53.6)$ & $59.5^{\mathrm{b}}(9.4-88.4)$ \\
\hline Pentamidine & $1.6^{\mathrm{b}}(0.06-63.4)$ & $\mathrm{nd}$ & $17.9^{\mathrm{c}}(2.4-25.8)$ \\
\hline Glucantime & nd & $17.4^{\mathrm{b}}(0.01-169.3)$ & $>100^{\mathrm{d}}$ \\
\hline
\end{tabular}

The different letters in the columns show the statistical difference between the $\mathrm{EC}_{50}$ values $(\mathrm{p}<0.05)$ by Tukey's test. $\mathbf{E C}_{\mathbf{5 0}}$ : $50 \%$ effective concentration; $95 \%$ CI: $95 \%$ confidence interval; nd: not determined.

*Values indicate the effective concentration of a compound in $\mu \mathrm{g} / \mathrm{mL}$ necessary to achieve $50 \%$ growth inhibition $\left(\mathrm{EC}_{50}\right)$.

The cytotoxicity of the compounds was determined in RAW 264.7 macrophages after 48 -h incubation. The cytotoxicity of the alkaloid (I) and acetogenin (II) isolated from A. squamosa, and the acetogenins corossolone (III) and annonacinone (IV) from A. muricata against RAW 264.7 murine macrophage cells showed values ranging from 43.5 to $79.7 \mu \mathrm{g} / \mathrm{mL}$. The standard drug glucantime showed toxicity to mammalian cells greater than $100 \mu \mathrm{g} / \mathrm{mL}$ (Table 2).

\section{DISCUSSION}

Leishmaniasis occurs globally. In particular, visceral leishmaniasis has a major impact in the Horn of Africa, South Asia, and Brazil, and cutaneous leishmaniasis in Latin America, Central Asia, and southwestern Asia. The species responsible for leishmaniasis in Latin America are divided in two taxonomic groups. The first is the subgenus Viannia, which mainly includes the species L. braziliensis, L. panamensis, and L. guyanesis, responsible for cutaneous or mucocutaneous lesions. The other is the Leishmania subgenus, which includes the species L. mexicana and L. amazonensis, responsible for localized or diffused skin lesions, and L. chagasi, which causes American visceral leishmaniasis ${ }^{14}$.

In this study, an alkaloid and three different acetogenins from two species of Annonacea plants, Annona squamosa and Annona muricata, were isolated. A. squamosa leaves contain a benzylisoquinolinic alkaloid, O-methylarmepavine (I), and a $\mathrm{C}_{37}$ trihydroxy adjacent bistetrahydrofuran acetogenin (II). From A. muricata seeds, two different acetogenins, corossolone (III) and annonacinone (IV), were isolated. These compounds were screened against Leishmania chagasi promastigote and amastigote forms, and their cytotoxicities were evaluated.

The leishmanicidal tests against $L$. chagasi using the alkaloid isolated from $A$. squamosa, $O$-methylarmepavine, revealed lower effectiveness when compared with the standard drug pentamidine. Tempone et al. tested the total alkaloid and ethanol extract from eight different Annonacea plants, which produce isoquinoline alkaloids, and showed effective results in vitro against L. chagasi. The most effective total alkaloid extract against promastigotes and amastigotes was that from Annona crassiflora.

The alkaloid $O$-methylarmepavine isolated from A. squamosa is a benzylisoquinolinic alkaloid. Isoquinoline and benzylisoquinoline analogues are the main leishmanicidal alkaloid types in the Annonacea family. Benzylisoquinolinic alkaloids are widely distributed in nature and have been isolated from different plants commonly used in traditional medicine for the treatment of parasitic diseases. Bisbenzylisoquinolinic alkaloids isolated from the stem bark of Guatteria boliviana have also been reported to show moderate activity when tested against promastigotes of L. donovani, L. amazonensis, and L. braziliensis ${ }^{5}$. Berberine, a quaternary isoquinolinic alkaloid, has been used in the clinical treatment of leishmaniasis, malaria, and amebiasis for more than 50 years and has shown in vitro and in vivo response against many species of Leishmania. This alkaloid, at a concentration of $10 \mu \mathrm{g} /$ $\mathrm{mL}$, effectively eliminates L. major parasites in peritoneal mice macrophages ${ }^{15,16}$. Another isoquinolinic alkaloid, isoguattouregidine, isolated from Guatteria foliosa, caused lysis of parasitic cell membrane when tested against L. donovani and L. amazonensis at a concentration of $100 \mu \mathrm{g} / \mathrm{ml}$. Anonaine and liriodenine obtained from the roots and trunk bark of $A$. pinescens showed an $\mathrm{IC}_{50}$ value of $100 \mu \mathrm{g} / \mathrm{mL}$ against promastigotes of L. braziliensis, L. amazonensis, and $L$. donovani ${ }^{17}$. About 20 bisbenzylisoquinoline alkaloids were screened for antileishmanial and antitrypanosomal activity in vitro; Fangchinoline $\left(\mathrm{IC}_{50} 0.39 \mu \mathrm{M}\right)$ was found to be as active as the standard drug pentamidine against Leishmania donovani promastigotes. Based on the above results, the leishmanicidal action of isoquinoline and benzylisoquinoline against the promastigote forms of Leishmania spp ranged from 0.39 to $100 \mu \mathrm{g} / \mathrm{mL}^{18}$. The mechanism of action of alkaloids is not completely understood, but Fournet et al. ${ }^{19}$ observed that bisbenzylisoquinolinic alkaloids inhibit an essential antioxidant enzyme in Leishmania, trypanothione reductase.

The acetogenin isolated from seeds of $A$. muricata, corossolone, showed the best activity among the three acetogenins used in this study. More than 160 different types of acetogenins are found in the Annonacea family. From the different species of Annonacea, 12 containing mono- and bis-THF ring acetogenins were isolated and tested against promastigotes and amastigotes of $L$. donovani. The results of this study against promastigotes showed a range between 2.5 and $47.3 \mu \mathrm{M}$. Rollinistatin was the most effective against amastigotes, with an $\mathrm{IC}_{50}$ value of $2.5 \mu \mathrm{M}$. Some acetogenins with one THF ring, such as senegalene, or two THF rings, such as squamocine, asimicine, and molvizarine, isolated from seeds of $A$. senegalensis showed activity against promastigotes of L. major and L. donovani at $25-100 \mu \mathrm{g} / \mathrm{mL}^{20}$.

Nine acetogenins with one or two THF rings were isolated from the seeds of A. glauca; their activity against L. donovani, L. braziliensis, and $L$. amazonensis was evaluated. The mono-THF ring acetogenins annonacin $\mathrm{A}$ and goniothalamicin showed activity against promastigotes, with $\mathrm{EC}_{100}$ values of 10 and $5 \mu \mathrm{g} / \mathrm{mL}$, respectively ${ }^{21}$.

In the amastigote assay using L. chagasi strains, the acetogenins from the two Annonacea species in the present study showed IC $_{50}$ values ranging from 13.5 to $28.7 \mu \mathrm{g} / \mathrm{mL}$, indicating the relevance of these compounds in the search for new leishmanicidal drugs. Regarding cytotoxicity, the alkaloid and all the acetogenins were more toxic to mammalian cells when compared with the standard drug.

The World Health Organization recommends pentavalent antimonials as first-choice drugs for leishmaniasis treatment. Although Glucantime has traditionally been used to treat leishmaniasis, its mechanisms of action and ability to induce damage in DNA are still unclear. In the study of Lima et al..$^{22}$, the genotoxic activity of this drug was evaluated in vitro using human lymphocytes, 
and in the in vivo tests, Swiss mice received acute treatment with three doses $(212.5,425$, and $850 \mathrm{mg} / \mathrm{kg}$ ) of pentavalent antimony. While no genotoxic effect was observed in the in vitro tests, the in vivo tests showed that Glucantime" induces DNA damage. The results of the authors indicate Glucantime" as a pro-mutagenic compound that causes damage to DNA after the reduction of pentavalent antimony (SbV) into the more toxic trivalent antimony (SbIII) in the antimonial drug meglumine antimoniate. These results encourage the search for other leishmanicidal compounds.

The chemotherapy for visceralleishmaniasis has been a great challenge, as the standard drugs used for treatment are toxic, and some strains are already resistant. Few studies using natural products against $L$. chagasi are carried out; therefore, the alkaloid and acetogenins isolated from A. squamosa leaves and A. muricata seeds are promising leishmanicidal agents, as they display a similar activity to glucantime in the in vitro assay. These plants are largely cultivated in Northeastern Brazil, producing agro-industrial waste material, which could be used in leishmaniasis phytotherapic treatment. Nevertheless, the in vitro toxicity indicates the need for in vivo tests for the production of safe phytotherapics.

\section{ACKNOWLEDGMENTS}

We are grateful to the CENAUREMN (Northeastern Center for the Application and Use of Nuclear Magnetic Resonance) of the Federal University of Ceará for the NMR spectra of the compounds. We also thank Dr. Selma M. B. Jerônimo, Dr. Daniella R.A. Martins, and Dr. Gloria R. G. Monteiro of the Biochemistry Laboratory of the Federal University of Rio Grande do Norte for their technical support in the development of this work.

\section{CONFLICT OF INTEREST}

The authors declare that there is no conflict of interest.

\section{FINANCIAL SUPPORT}

Conselho Nacional de Desenvolvimento Científico e Tecnológico (CNPq), Fundação Cearense de Apoio ao Desenvolvimento Científico e Tecnológico (FUNCAP), and research projects supported by Sistema Único de Saúde (PPSUS).

\section{REFERENCES}

1. Croft SL, Coombs GH. Leishmaniasis - current chemotherapy and recent advances in the search for novel drugs. Trends Parasitol 2003; 19:502-508.

2. Ashford DA, Desjeux P, Raadt P. Estimation of population at risk of infection and number of cases of leishmaniasis. Parasitol Today 1992; 8:104-105.

3. Desjeux P. Urbanization: An increasing risk factor for leishmaniasis. World Health Organization, Weekly Epidemiol Record 2002; 44:365-372.

4. Costa CHN, Stewart JM, Gomes RB, Garcez LM, Ramos PKS, Bozza M, et al. Asymptomatic human carriers of Leishmania chagasi. Am J Trop Med Hyg $2002 ; 66: 334-337$

5. Chan-Bacab MJ, Pena-Rodríguez LM. Plant natural products with leishmanicidal activity. Roy Soc Chem 2001; 18:674-688.

6. Osorio E, Arango GJ, Jiménez N, Alzate F, Ruiz G, Gutiérrez D, et al. Antiprotozoal and citotoxic activities in vitro of Colombian Annonaceae. J Ethnopharmacol 2007; 111:630-635.

7. Tempone AG, Borborema SET, Andrade HF, Gualda NCA, Yogi A, Carvalho CS, et al. Antiprotozoal activity of Brazilian plant extracts from isoquinoline alkaloidsproducing families. Phytomed 2005; 12:382-396.
8. Piazza RMF, Andrade HF, Umezawa ES, Katzin M, Stolf AMS In situ immunoassay for the assessment of Trypanosoma cruzi interiorization and growth in cultured cells. Acta Trop 1994; 57:301-306.

9. Souza MMC, Bevilaqua CML, Morais SM, Costa CTC, Silva ARA, Braz-Filho R Anthelmintic acetogenin from Annona squamosa L. seeds. An Acad Bras Cien 2007; 80:271-277.

10. Bhakuni DS, Tewari S, Dhar MM. Alkaloids from leaves of Annona squamosa. Phytochem 1979; 18:1584-1586.

11. Bhakuni DS, Tewari S, Dhar MM. Aporphine alkaloids of Annona squamosa. Phytochem 1972; 11:1819-1822.

12. Cortes D, Myint SH, Laurens A, Hocquemiller R, Leboeuf M, Cavé A. Corossolone et corossoline, deux nouvelles y-lactones mono-tetrahydrofuraniques cytotoxiques. Can J Chem 1991; 69:8-11.

13. Xu L, Chang CJ, Yu JG, Cassady JM. Chemistry and selective cytotoxicity of annonacin-10-one, isoannonacin, and isoannonacin-10-one. Novel polyketides from Annona densicoma (Annonaceae). J Org Chem 1989; 54:5418-5412.

14. Pereira-Chioccola VL. Diagnóstico molecular das leishmanioses: contribuição ao Programa de Vigilância e Controle da LVA no Estado de São Paulo. BEPA. Bol Epidemiol Paul (online) 2009; 6:4-13.

15. Phillipson JD, Wright CW. Medicinal plants against protozoal diseases. Trans R Soc Trop Med Hyg 1991; 85:18-21.

16. Aniszewski T. Alkaloids - Secrets of Life. $1^{\text {st }}$ ed. Hardbound, Finland: Elsevier 2007

17. Mahiou V, Roblot F, Hocquemiller R, Cave A, Rojas de Arias A, Inchausti A, et al. Aporphine alkaloids from Guatteria foliosa. J Nat Prod 1994; 57:890-895.

18. Camacho MR, Phillipson JD, Croft SL, Rock P, Marshall SJ, Schiff Jr PL. In vitro activity of Triclisia patens and some bisbenzylisoquinoline alkaloids against Leishmania donovani and Trypanosoma brucei brucei. Phytother Res 2002; 16:432-436.

19. Fournet A, Rojas A, Ferreira ME, Nakayama H, Torres-de-Ortiz S, Schinini A, et al Efficacy of the bisbenzylisoquinoline alkaloids in acute and chronic Trypanosoma cruzi murine model. Int J Antimicrob Agents 2000; 13:189-195.

20. Grandic SR, Fourneau C, Laurens A, Bories C, Hocquemiller R, Loiseau PM In vitro antileishmanial activity of acetogenins from Annonaceae. Biomed Pharmacother 2004; 58:388-392.

21. Waechter A, Yaluff G, Inchausti A. Leishmanicidal and trypanocidal activities of acetogenins isolated from Annona glauca. Phytother Res 1998; 12:541-544.

22. Lima MIS, Arruda VO, Carneiro Alves EC, Azevedo APS, Monteiro SG Pereira SRF. Genotoxic effects of the antileishmanial drug glucantime®. Arch Toxicol 2010; 84:327-332. 